\title{
Diffuse-Reflectance Fourier-Transform Mid-Infrared Spectroscopy as a Method of Characterizing Changes in Soil Organic Matter
}

\author{
Francisco Calderón* \\ USDA-ARS \\ Central Great Plains Research Station \\ 40335 County Rd GG \\ Akron, CO 80520
}

\section{Michelle Haddix \\ Richard Conant \\ Natural Resource Ecology Lab. \\ Colorado State Univ. \\ Fort Collins, CO 80523}

Kimberly Magrini-Bair National Renewable Energy Lab. Golden, CO 80401

\section{Eldor Paul}

Natural Resource Ecology Lab. Colorado State Univ. Fort Collins, CO 80523
Diffuse-reflectance Fourier-transform mid-infrared spectroscopy (MidIR) can identify the presence of important organic functional groups in soil organic matter (SOM); however, spectral interpretation needs to be validated to correctly assess changes in SOM quality and quantity. We amended soils with known standards, increasing the total $\mathrm{C}$ in the sample by $50 \%$, and measured changes in MidIR spectra. Adenine, casein, cellulose, ergosterol, glucosamine, glycine, guanine, indole, methionine, palmitic acid, egg protein, chlorophyllin, tannic acid, xylose, urease, and vanillin standards were used. In addition, corn (Zea mays L.) stalk feedstock and two chars produced at different temperatures were studied. Two soils were used: a Hoytville, OH, soil $(2.5 \% \mathrm{C}$ and $36 \%$ clay) and an Akron, CO, soil $(1.5 \% \mathrm{C}$ and $14 \%$ clay). The addition of standards with $>10 \% \mathrm{~N}$ content resulted in increased amide-like absorbance at 1670,1588 , and $1513 \mathrm{~cm}^{-1}$. Bands at 2970 to 2800,2200 to 2000 , and 1030 to $1160 \mathrm{~cm}^{-1}$ were sensitive to added polysaccharide. Protein addition increased absorption at 2970 to $2800 \mathrm{~cm}^{-1}$ but also increased the 1691 and $1547 \mathrm{~cm}^{-1}$ amide bands. Vanillin addition resulted in higher absorbance at the 1592, 1515, and $1295 \mathrm{~cm}^{-1}$ aromatic $\mathrm{C}=\mathrm{C}$ bands. Biochars produced at $300^{\circ} \mathrm{C}$ resulted in increased absorbance at carbonyl and aliphatic bands, while addition of $500^{\circ} \mathrm{C}$ biochar increased aromatic absorbance. Our results showed that MidIR is sensitive to relatively small changes in SOM. If assumptions about the soil mineralogy are met, specific spectral bands can be used to follow changes in SOM chemistry.

Abbreviations: MidIR, diffuse-reflectance Fourier-transform mid-infrared spectroscopy; NMR, nuclear magnetic resonance spectroscopy; SOM, soil organic matter.

I

$\mathrm{t}$ is challenging to characterize SOM constituents because soils contain a staggering variety of organic $\mathrm{C}$ compounds at varied stages of decomposition, from relatively fresh plant residues to highly processed aromatics and older nonhydrolyzable molecules (Stout et al., 1981; Follett et al., 2007). The presence of and interactions with the mineral matrix further complicates interpretation of the results.

Analysis of soil organic $\mathrm{C}$ pools involves procedures such as combustion analysis for CHN, nuclear magnetic resonance spectroscopy (NMR) (Hemminga and Buurman, 1997), fumigation-incubation for microbial biomass, wet chemistry extraction (Steelink, 2002), lignin quantification (Thevenot et al., 2010), the use of radioisotopes for quantification of turnover and C dating (Calderón et al., 2012; Paul et al., 1997), hydrolysis procedures for quantifying highly recalcitrant $C$, and incubationcurve fitting for the determination of fast- and slow-turnover $\mathrm{C}$ pools (Paul et al.,

\footnotetext{
Mention of trade names or commercial products in this publication is solely for the purpose of providing specific information and does not impy recommendation or endorsement by the U.S. Department of Agriculture. USDA is an equal opportunity provider and employer.

Soil Sci. Soc. Am. J. 77:1591-1600

doi:10.2136/sssaj2013.04.0131

Supplemental material is available online for this article.

Received 11 Apr. 2013.

*Corresponding author (francisco.calderon@ars.usda.gov).

(C) Soil Science Society of America, 5585 Guilford Rd., Madison WI 53711 USA

All rights reserved. No part of this periodical may be reproduced or transmitted in any form or by

any means, electronic or mechanical, including photocopying, recording, or any information storage and retrieval system, without permission in writing from the publisher. Permission for printing and for reprinting the material contained herein has been obtained by the publisher.
} 
2006). All these techniques have been very useful for expanding our understanding of SOM chemistry. Recent advances in infrared spectroscopy indicate that it will become an important tool for the study of soils, especially when combined with other technologies (Davinic et al., 2012).

Spectroscopic techniques like infrared spectroscopy and NMR have been used to study SOM because both techniques can detect important organic functional groups. Nuclear magnetic resonance spectroscopy can give a semiquantitative understanding of carboxylic, aliphatic, and aromatic groups in soils (Hemminga and Buurman, 1997). Pyrolysis-molecular beam mass spectrometry (py-MBMS) is another potentially valuable way for studying SOM because it can detect high-molecular weight fragments from the nonoxidative breakup of SOM (Magrini et al., 2007). Infrared and NMR spectra, as well as pyMBMS data, need to be interpreted judiciously because they all have the potential for interference or artifacts associated with soil minerals. The question of how quantitative these techniques can be has not yet been answered definitively. Nevertheless, the study of SOM via mid- and near-infrared spectroscopy is undergoing exponential growth due to its convenience, quickness, and relatively low cost and because of the information-rich nature of the data (Bellon-Maurel and McBratney, 2011).

Diffuse-reflectance Fourier-transform mid-infrared spectroscopy, also known as DRIFT, can be used quickly and nondestructively to quantify total soil $\mathrm{C}$ and other soil properties (McCarty et al., 2002; Leifeld, 2006; Viscarra Rossel et al., 2006). Calibrations for total $\mathrm{C}$ integrate all the information in the MidIR spectra. The infrared spectrum can "see" important C functional groups in SOM and can complement other techniques, like NMR, for the quantification of alkyl-C, aromatic-C, and carboxyl-C (Leifeld, 2006). Spectral interpretation can be used to dig deeper into the spectral data. However, to identify and quantify the presence of important organic functional groups in environmental samples by observing fluctuations in specific spectral bands (Nguyen et al., 1991; Calderón et al., 2011a, 2011b; Demyan et al., 2012). Many of the functional groups to which MidIR bands are ascribed, such as aromatics, carbonyls, and aliphatics, cannot be quantified in soils by means of traditional chemistry. This precludes a side-by-side comparison of spectral data and chemical data. Because of this, MidIR spectral analysis should be validated by spiking soils with known organic standards to correctly interpret changes in the expected spectral features. Further, soils are mostly made up of mineral rather than organic material, so tests about how small changes in organic matter affect MidIR spectra are needed to make more accurate spectral interpretations. We hypothesized that compounds that contain functional groups that absorb in the MidIR will cause predictable spectral differences on addition to soils.

Previous work on spectral interpretation of soil MidIR data has used ashing and spectral subtraction to bring out the absorbance bands attributable to the soil organics (Cox et al., 2000; Calderón et al., 2011a, 2011b). Very few studies have tested the usefulness and limitations of spectral subtraction on soils. The hypothesis is that subtracting the soil spectrum from the mixture spectrum results in the absorbance contribution of the added pure compound. Ashing and subtraction must be used judiciously because of subtraction artifacts brought about by heat-induced changes in clays that affect the 1500 to $400 \mathrm{~cm}^{-1}$ region (Reeves, 2012a), yet the regions between 3000 and $2800 \mathrm{~cm}^{-1}$ and 1750 to $1600 \mathrm{~cm}^{-1}$ can be subtracted reasonably well in low-carbonate or decalcified soils (Reeves, 2012a).

The purpose of this project was to determine whether MidIR is sensitive to relatively small additions of organic compounds. We amended soils with known quantities of standards including lipids, carbohydrates, amino acids, and proteins. We scanned the soils alone, the standards alone, and mixtures of soil and standards using MidIR. One specific question we wanted to answer was: can we detect small additions of organic $\mathrm{C}$ and $\mathrm{N}$ ? The long-term objective of this project is to determine if we can use MidIR to interpret soil $\mathrm{C}$ dynamics after changes in agricultural management or environmental disturbance. We utilized two different soils with varying $\mathrm{C}$ and clay contents and added known compounds to the soils to increase the $\mathrm{C}$ content by $50 \%$. We then used multivariate analysis and spectral subtraction to test the sensitivity of MidIR to detect changes in the $\mathrm{C}$ chemistry within a soil matrix.

\section{MATERIALS AND METHODS Soil Sampling}

Soil samples (0-20-cm depth) from two sites with different $\mathrm{C}$ and clay compositions were chosen for the study. The two soils were: (i) an Aridic Paleustoll from Akron, $\mathrm{CO}\left(40^{\circ} 9^{\prime} \mathrm{N}, 103^{\circ} 8^{\prime}\right.$ W) under native grassland with $1.46 \% \mathrm{C}, 0.18 \% \mathrm{~N}, 49.6 \%$ silt, and $14.3 \%$ smectitic clay; and (ii) a Mollic Ochraqualf from Hoytville, $\mathrm{OH}\left(41^{\circ} 0^{\prime} \mathrm{N}, 84^{\circ} 0^{\prime} \mathrm{W}\right)$ originally under a temperate forest but now under no-till corn (Zea mays L.) with $2.48 \% \mathrm{C}$, $0.28 \% \mathrm{~N}, 45.01 \%$ silt, and $35.9 \%$ illitic clay. The $\mathrm{pH}$ of both soils was slightly acidic (6.7 for Akron and 6.1 for Hoytville) and they were carbonate free. Three replicates from randomly selected field locations were sampled from each site. After sampling, the soil was sieved $(2 \mathrm{~mm})$ to exclude any rocks and coarse plant material.

\section{Mixing of Soils and Standards}

The standards listed in Table 1 were mixed with the soils to increase the soil C content by $50 \%$, to $2.19 \% \mathrm{C}\left(21.9 \mathrm{~g} \mathrm{~kg}^{-1}\right)$ for the Akron soil and $3.72 \%\left(37.2 \mathrm{~g} \mathrm{~kg}^{-1}\right.$ ) for the Hoytville soil. We chose this quantity so that the added standard $\mathrm{C}$ was within the range of $\mathrm{C}$ changes that could be attained by soil management and to allow the presence of predominantly soil-derived spectral bands in the mixtures. In addition to the $50 \%$ mixing scheme used for all the standards, cellulose was mixed with the soil to increase the soil C by 25,50 , and $100 \%$. Before mixing, both the soil and the standards were dried overnight at $60^{\circ} \mathrm{C}$. Temperature-sensitive standards (indole and palmitic acid) were placed in a desiccator overnight instead of oven dried. After mixing, the compounds were stored in sealed vials. Soils and standards were mixed as dry powders. A mortar and pestle was used to ensure thorough mixing and grinding. Soils and standards 
were analyzed for total $\mathrm{C}$ and $\mathrm{N}$ with a Leco $\mathrm{CN}$ analyzer. The amount of each standard added to the soils varied due to the different $\mathrm{C}$ content of the standards, which ranged from $33 \%$ in glycine to $>76 \%$ in the lipids and indole. The standards varied in $\mathrm{N}$ content from zero in the lipids and tannic acid to $>44 \%$ in the purine nitrogenated bases (Table 1).

\section{Biochar}

Corn stalk material was obtained after harvest, oven dried $\left(60^{\circ} \mathrm{C}\right)$, and shredded. The biochars were generated by a procedure developed in our laboratory and detailed in Reeves (2012b). Briefly, the corn material was packed into 125-mL Erlenmeyer flasks, and the empty space at the top was filled with glass wool. The flasks were then topped with a $50-\mathrm{mL}$ beaker. The biochars were produced at the prescribed temperatures for $45 \mathrm{~min}$ in a muffle furnace, after which time they were brought to room temperature. The corn stalk material lost $46.3 \%$ of its mass on charring at $300^{\circ} \mathrm{C}$ and $69.8 \%$ at $500^{\circ} \mathrm{C}$. The $300^{\circ} \mathrm{C}$ char had a pH of 6.0, and the $500^{\circ} \mathrm{C}$ char had a $\mathrm{pH}$ of 7.5. The corn stalks were $43.3 \% \mathrm{C}$, the $300^{\circ} \mathrm{C}$ char was $57.9 \% \mathrm{C}$, and the $500^{\circ} \mathrm{C}$ char was $69.8 \% \mathrm{C}$.

\section{Infrared Spectroscopy}

The soils and soil-standard mixtures were finely ground using a mortar and pestle before scanning. All soil samples were scanned in diffuse reflectance from 4000 to $400 \mathrm{~cm}^{-1}$ undiluted with a Digilab FTS 7000 (Varian) with a deuterated triglycine sulfate (DTGS) detector and a $\mathrm{KBr}$ beam splitter; $\mathrm{KBr}$ was used as background. The background spectrum was subtracted from each recorded spectrum. Each spectrum consisted of 64 co-added scans at $4 \mathrm{~cm}^{-1}$ resolution. Each sample was scanned in duplicate and the duplicate spectra were averaged. The spectra for the reference standards and soils are shown in Supplemental Fig. 1.

\section{Multivariate Analysis and Spectral Subtractions}

Principal components analysis (PCA), spectral averages, and subtractions were calculated using GRAMS/AI and GRAMS/ IQ software, Version 9.1 (Thermo Galactic).

\section{RESULTS}

\section{Principal Components Analysis of the Spectra}

The PCA shows that the main differences in the soil and soilstandard mix spectra are attributable to the soils (Akron vs. Hoytville), which are separated completely along Component 1 (Fig. 1). The correlation between the spectral data and each component is indicated by the loadings. Component loadings in Fig. 2 indicate that the Akron soils, with higher Component 1 scores, have more absorbance near the $3630 \mathrm{~cm}^{-1}$ clay band, the 3600 to 3400 $\mathrm{cm}^{-1} \mathrm{OH}-\mathrm{NH}$ absorbance region, the 2000 to $1790 \mathrm{~cm}^{-1}$ quartz bands, and at 1626, 1532 (amide), and $1329 \mathrm{~cm}^{-1}$ (Fig. 2; Table 2). Absorbance at $1626 \mathrm{~cm}^{-1}$ could be due to clay-bound water, but the lower clay content of the Akron soils suggests that this band may be at least partially due to amide or aromatics. The Hoytville soils absorbed more than the Akron soils at 1562 (amide), 1423, 1164 , and $1048 \mathrm{~cm}^{-1}$ (polysaccharide C-O) (Table 2).

The distribution of the standard-soil mixtures along Component 2 is very similar between the Akron and Hoytville soils. The mixtures with urease, tannic acid, and palmitic acid caused the least spectral differences and group nearest to their respective unamended soils (Fig. 1). Adenine, methionine, casein, egg protein, and ergosterol caused the most spectral differences compared with the soil-alone spectra. For both Akron and Hoytville, the unamended soils as well as the tannic acid, egg protein, and casein mixes have high Component 1 scores, while the adenine and methionine mixes have low Component 1 scores. Loadings indicate that high Component 1 scores are partly due to clay and silicate absorbance (Fig. 2). Low Component 1 scores are due to high absorbance at 1210 to 1140 and 1070 to $1000 \mathrm{~cm}^{-1}$, suggesting organic absorbance and/or blockage and reduction of specular reflection from silicates in the soils by the added standards.

The guanine, adenine, methionine, and egg protein mixtures have high Component 2 scores due to absorbance at 1670,1588, 1513 , and $1415 \mathrm{~cm}^{-1}$, which suggests amide or deformation $\mathrm{C}-\mathrm{H}$ absorbance (Table 2). The mixtures with casein, cellulose, and ergosterol have low Component 2 scores, indicating higher absorbance at 3630 to 3450 and 1250 to $1050 \mathrm{~cm}^{-1}$ (Fig. 2; Table 2). Note that the nitrogenous bases adenine and guanine are almost $50 \% \mathrm{~N}$ (Table 1). The PCA shows that soil mixes with N-containing standards of $>10 \% \mathrm{~N}$ content tended to have positive Component 2 scores compared with the samples that received zero-N 


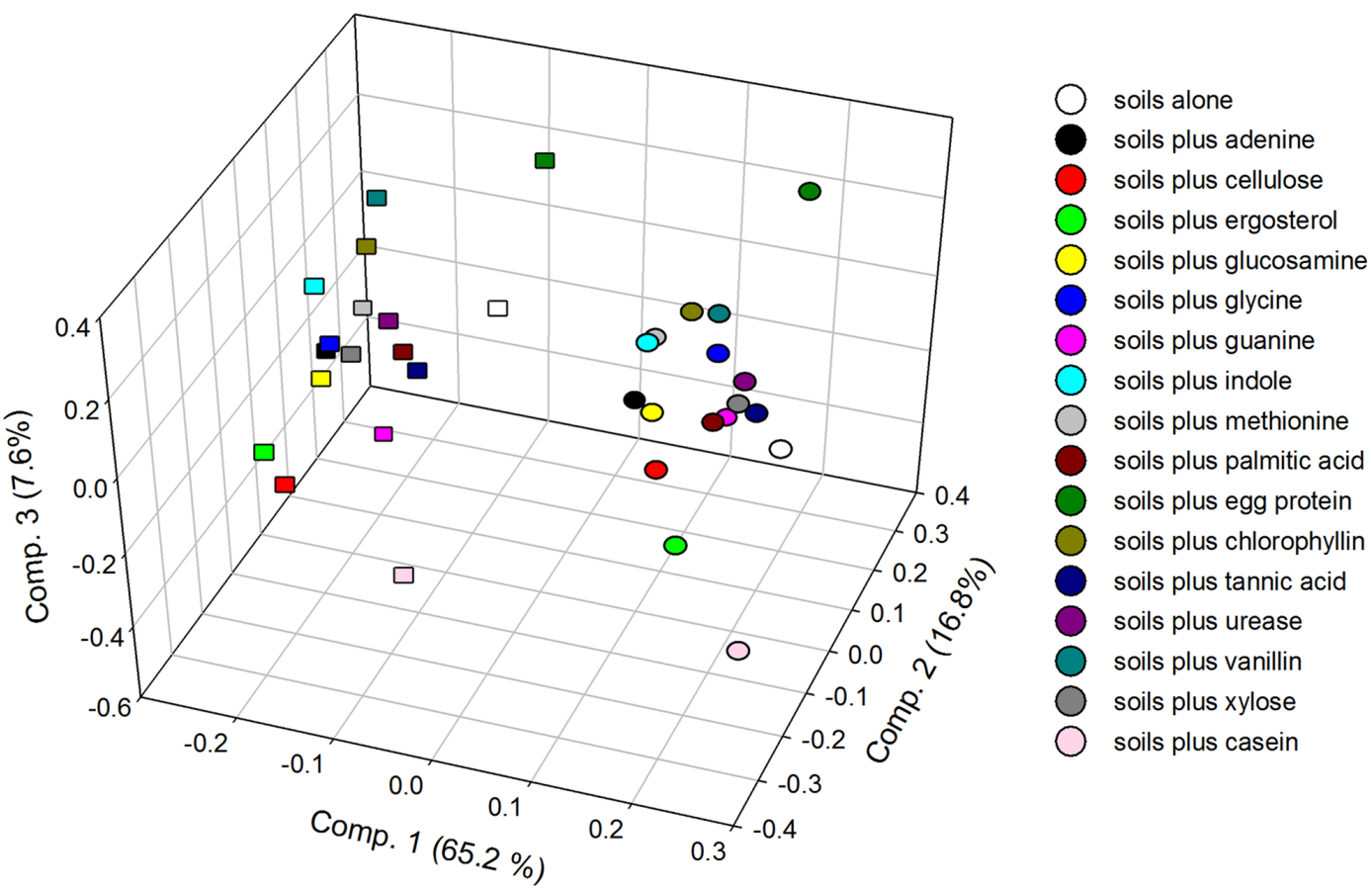

Fig. 1. Principal components analysis of the mid-infrared spectra of the soils and soil-standard mixtures. The Akron soils are the circles and the Hoytville soils are the squares. The percentage of the total variance explained by each component is shown in parentheses.

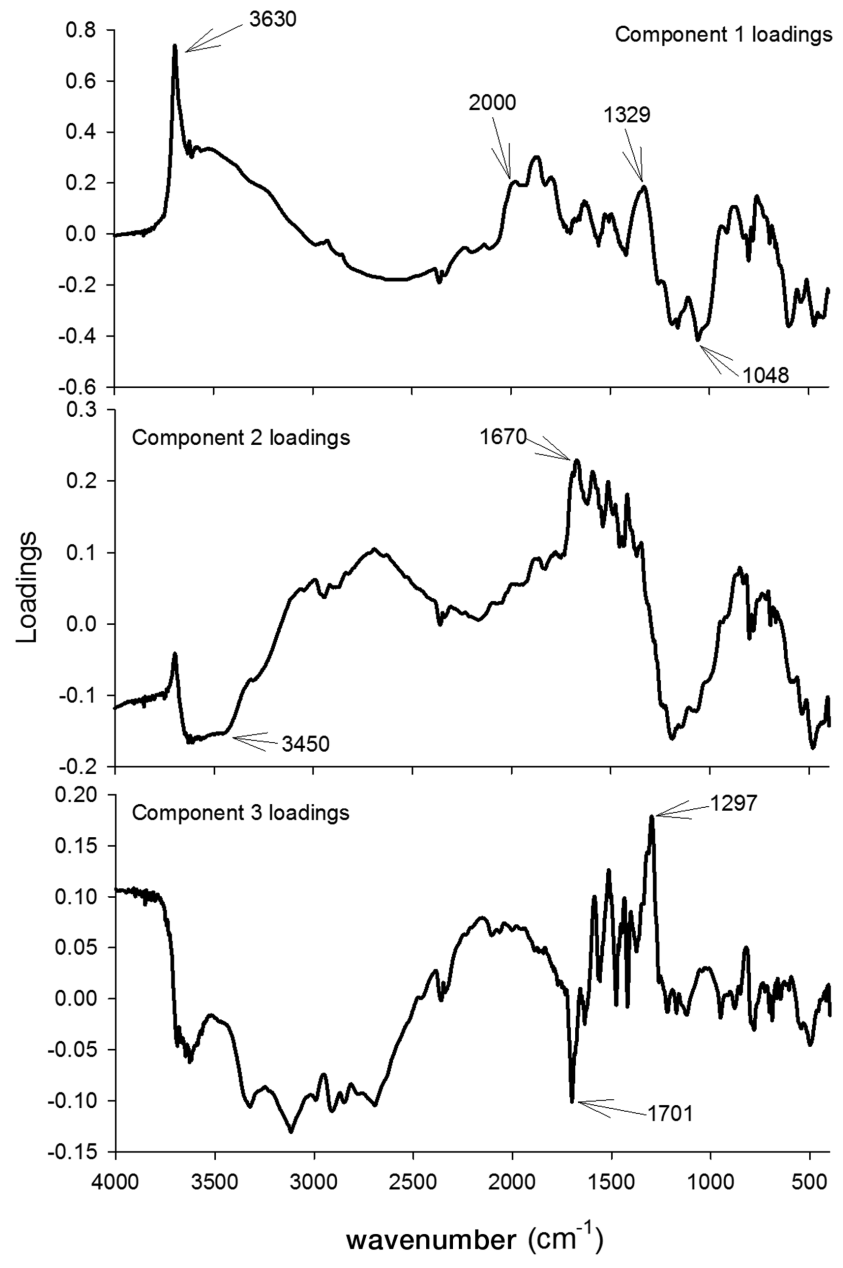

Fig. 2. Component loadings for the principal components analysis shown in Fig. 1. standards within each soil type. The casein mix was an exception, with low Component 2 scores despite being a protein. Loadings also indicate that the addition of casein, cellulose, and ergosterol is consistent with increased $\mathrm{OH}, \mathrm{NH}$, and carbonyl bands (Table 2).

The mixtures with indole, ergosterol, chlorophyllin, vanillin, and egg protein have high Component 3 scores, indicating increased absorbance at $1585,1515,1436,1402$, and $1297 \mathrm{~cm}^{-1}$ (Fig. 2). The guanine, casein, methionine, and adenine mixtures have low Component 3 scores. Low Component 3 loadings are associated with increased absorption at 3326, 3118, 1701, 1635, 1559, 1478, 1219, 1174, and $1122 \mathrm{~cm}^{-1}$ (Fig. 2). These bands suggest the influence of $\mathrm{N}-\mathrm{H}$, amide-like, aromatic $\mathrm{C}=\mathrm{C}$, and carbonyl absorbance (Table 2).

\section{Spectral Subtraction of Standard-Soil Mixes}

We performed spectral subtractions of soil-standard mixes minus the soil alone for all the standards. Here we discuss the results from four compounds that are particularly interesting because of their different chemistries: cellulose (lacks $\mathrm{N}$ and should show typical carbohydrate bands on subtraction), methionine (should show N-containing spectral bands), casein (a protein that should result in amide absorbance), and vanillin, which should show aromatic-type bands.

The addition of cellulose resulted in an increase in absorbance at $3400 \mathrm{~cm}^{-1}$, which should be due mostly to $\mathrm{OH}$ absorbance and not NH in this case (Fig. 3). The region between 2970 and 2800 $\mathrm{cm}^{-1}$ also subtracted well. The rise between 2200 and $2000 \mathrm{~cm}^{-1}$ observed in the pure compound spectrum corresponds to overtones of the $-\mathrm{COH}$ stretch (Table 2). This band can also be seen in the subtracted spectra, although this feature is not as prominent 
Table 2. Putative assignments for the bands relevant to this study. Note that mid-infrared absorption bands occur across a range and that there are overtone and combination bands from several different functional groups that may overlap with these frequencies.

\begin{tabular}{|c|c|}
\hline Wavenumber & Assignment \\
\hline \multicolumn{2}{|l|}{$\mathrm{cm}^{-1}$} \\
\hline 3630 & stretching $\mathrm{O}-\mathrm{H}$ in clays ${ }^{-}$ \\
\hline 3400 & stretching $\mathrm{O}-\mathrm{H}$ and stretching $\mathrm{N}-\mathrm{H} \neq$ \\
\hline $2930-2870$ & stretching $\mathrm{C}-\mathrm{H} \S$ 政 \\
\hline $2200-2000$ & overtones of stretching $-\mathrm{COH} \#$ in aliphatics \\
\hline $2000-1790$ & quartz overtones $\dagger$ \\
\hline $1625-1630$ & mineral-bound water \\
\hline $1625-1670$ & $\begin{array}{l}\text { amide I or phenyl ring stretching } \mathrm{C}=\mathrm{C} \neq \text {, stretching } \mathrm{C}=\mathrm{O} \text { of } \\
\text { amide groups and nucleic acids, carboxyl }\end{array}$ \\
\hline $1570-1590$ & ring stretching $\mathrm{C}=\mathrm{C}$ of phenyl $\neq$, carboxylate stretching $\mathrm{C}=\mathrm{O}$ \\
\hline $1480-1560$ & $\begin{array}{l}\text { amide II band stretching } \mathrm{C}-\mathrm{N} \text { and bending } \mathrm{C}-\mathrm{N}-\mathrm{H} \neq \S \text {, also } \\
\text { bending } \mathrm{CH} \text { in phenyl rings }\end{array}$ \\
\hline 1530 & stretching $\mathrm{C}=\mathrm{N}$ or stretching $\mathrm{C}=\mathrm{C} \neq$ \\
\hline $1400-1450$ & $\begin{array}{l}\text { bending }\left(\mathrm{CH}_{2}\right) \text { in polysaccharides and proteins } \neq \text {, also } \mathrm{N}-\mathrm{H} \\
\text { and stretching } \mathrm{C}-\mathrm{N}\end{array}$ \\
\hline 1330 & $\begin{array}{l}\text { stretching } \mathrm{C}-\mathrm{N} \text { in amides, bending }(\mathrm{CH}) \text { in phenyls and } \\
\text { polysaccharides } \neq\end{array}$ \\
\hline $1220-1320$ & amide III band‡ \\
\hline $1060-1170$ & stretching $\mathrm{C}-\mathrm{O}$ in carbohydrates, nucleic acids, proteinsł \\
\hline 1050 & bending $\mathrm{C}-\mathrm{O}$ in carbohydrates $\neq$ \\
\hline $1020-950$ & stretching $\mathrm{Si}-\mathrm{O}+$ \\
\hline
\end{tabular}

+ Nguyen et al. (1991).

₹ Movasaghi et al. (2008).

$\S$ Haberhauer and Gerzabek, (1999).

ฯ Leifeld, (2006).

\# Janik et al. (2007).

as the carbonyl band between at 1030 to $1160 \mathrm{~cm}^{-1}$, which we show to be a particularly sensitive region to cellulose addition.

The methionine subtractions had higher values at 3050 to $2500,2094,1670$ to 1580,1530 to 1490,1450 to 1400,1360 to 1330, and 1230 to $970 \mathrm{~cm}^{-1}$ (Fig. 4). This shows that amino acids increase absorption due to various modes of $\mathrm{N}-\mathrm{H}, \mathrm{C}-\mathrm{O}$, and $\mathrm{C}-\mathrm{H}$ vibrational absorption (Table 2). Several peaks between 1180 and $870 \mathrm{~cm}^{-1}$ present in the pure methionine spectrum did not have a marked effect on the subtracted spectrum. The casein addition subtraction data support the results of the PCA analysis (Fig. 1), with absorption increases near 3400 to 3200,2970 to 2850,1700 to 1614,1560 to 1490,1460 to 1400 , and 1260 to $1170 \mathrm{~cm}^{-1}$ (Fig. $5)$, which show that the added protein affected absorption bands associated with $\mathrm{C}=\mathrm{O}$ and amide functional groups (Table 2).

Spectral subtraction of the vanillin-amended soils shows that the $1670 \mathrm{~cm}^{-1}$ as well as the aromatic $\mathrm{C}=\mathrm{C}$ bands at 1592 , 1515 , and $1295 \mathrm{~cm}^{-1}$ are all amenable to subtraction (Fig. 6).

The spectral subtraction using palmitic acid was included despite this standard being one of the additives that caused the least spectral differences within the standard set (Fig. 1). This standard, however, caused a very marked increase in absorbance at 2920 and $2850 \mathrm{~cm}^{-1}$, as expected from a molecule with a large quantity of aliphatic $\mathrm{CH}$ bonds (Supplemental Fig. 1). In addition, palmitic acid also resulted in less marked increased absorbance at 1691 and $1465 \mathrm{~cm}^{-1}$ near the carboxylic acid $\mathrm{C}=\mathrm{O}$ bond stretching and

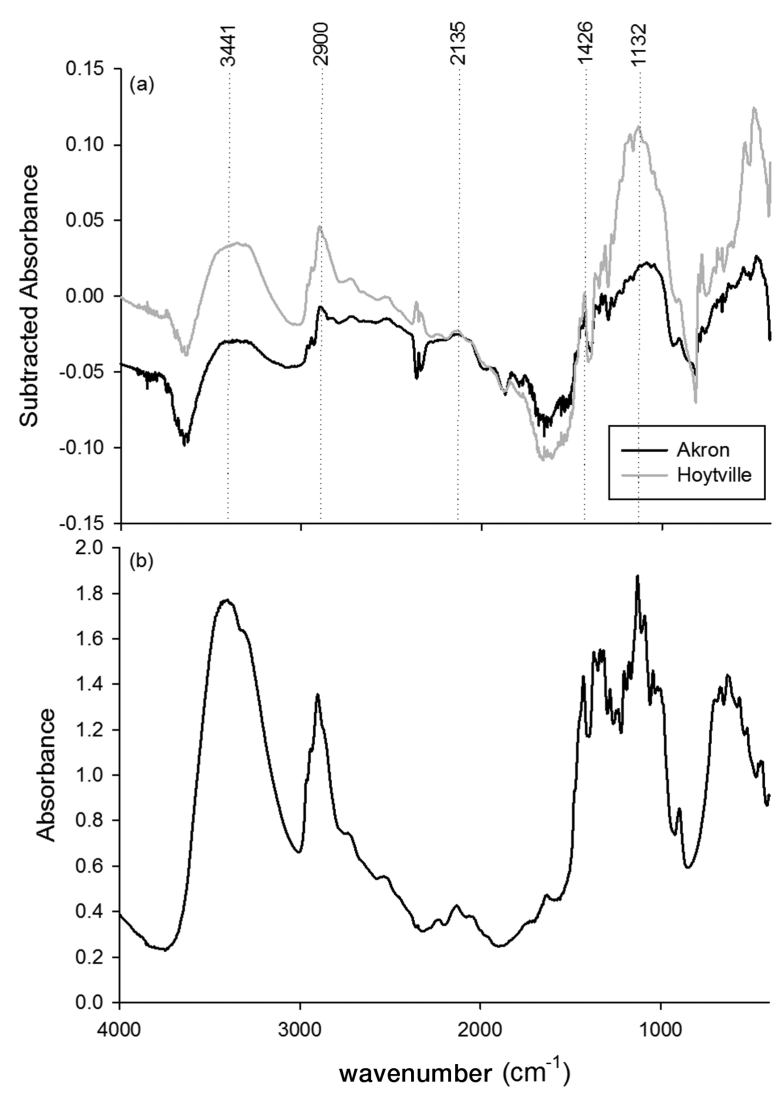

Fig. 3. (a) Spectral subtraction of the cellulose-soil mixes and (b) midinfrared spectra of cellulose.

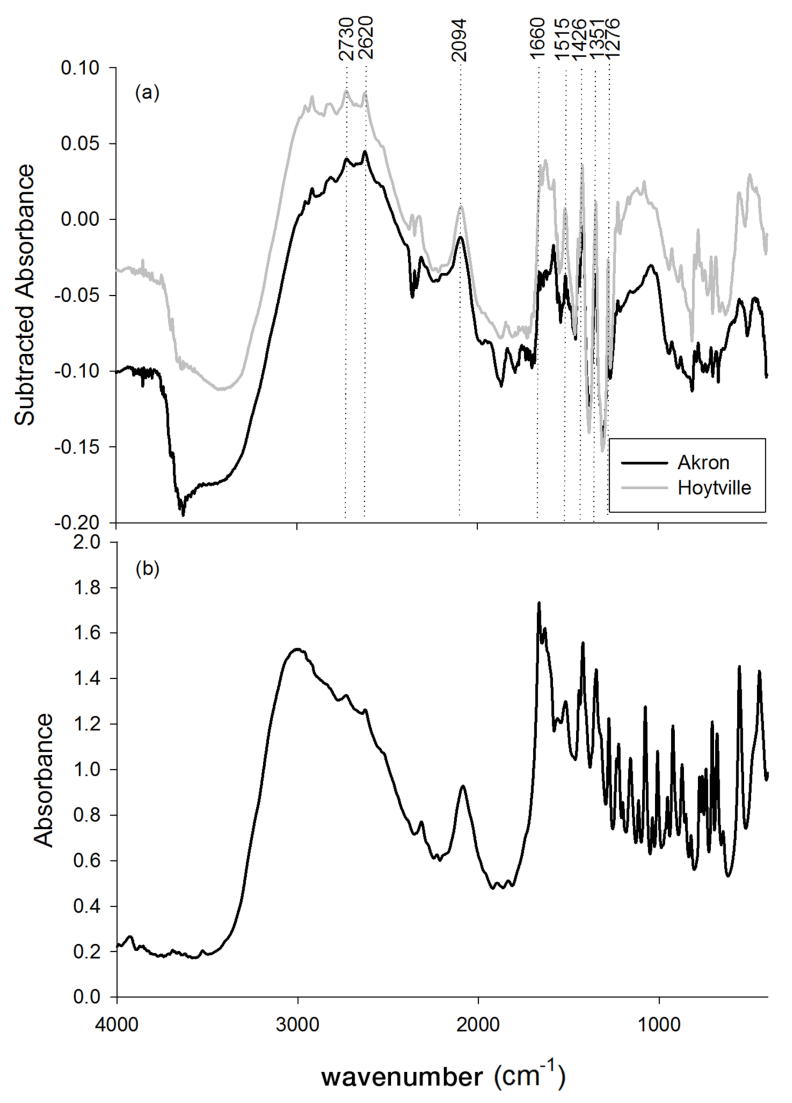

Fig. 4. (a) Spectral subtractions of the methionine-soil mixes and (b) mid-infrared spectra of methionine. 


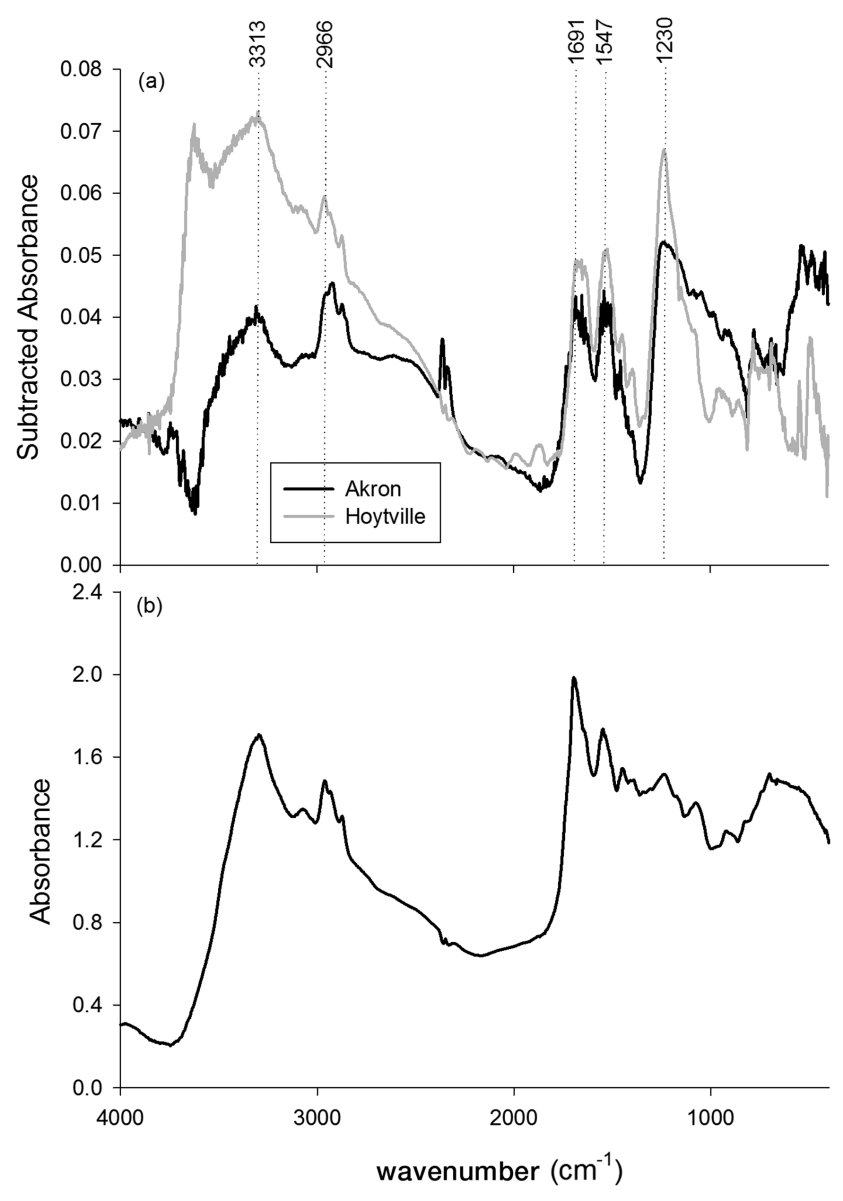

Fig. 5. (a) Spectral subtractions of the casein-soil mixes and (b) midinfrared spectra of casein.

the lipid acyl chain $\mathrm{CH}_{2}$ scissoring (Movasaghi et al., 2008). Like palmitic acid, ergosterol increased absorbance in the $\mathrm{CH}$ bands between 2960 and $2870 \mathrm{~cm}^{-1}$ but to a lesser extent than the fatty acid.

During the review process it was suggested that biochars should be part of the study, given their importance as a soil component in many soils. The $300^{\circ} \mathrm{C}$ charring caused a decrease in absorbance at the $3400 \mathrm{~cm}^{-1} \mathrm{OH} / \mathrm{NH}$ band, and the disappearance of the $\mathrm{C}=\mathrm{O}$ stretching peak at $1740 \mathrm{~cm}^{-1}$ (Fig. $7 \mathrm{a}$ ). Bands at 1240 and 1170 to $1100 \mathrm{~cm}^{-1}$ were also lost at $300^{\circ} \mathrm{C}$, but the $300^{\circ} \mathrm{C}$ char has a carbonyl peak at $1700 \mathrm{~cm}^{-1}$ that is not found in the uncharred stalks. Charring at $500^{\circ} \mathrm{C}$ resulted in the disappearance of the aliphatic $\mathrm{CH}$ band between 2970 and $2830 \mathrm{~cm}^{-1}$ and the carbonyl peak at $1700 \mathrm{~cm}^{-1}$ and an increase in the baseline between 4000 and $2000 \mathrm{~cm}^{-1}$. The $500^{\circ} \mathrm{C}$ treatment produced bands at 3050 and 880 to $780 \mathrm{~cm}^{-1}$ (both due to aromatic $\mathrm{C}-\mathrm{H}$ ) not found in the $300^{\circ} \mathrm{C}$ biochar (Fig. 7a). Absorbance at $1600 \mathrm{~cm}^{-1}$, due to stretching modes of aromatics with multiple $\mathrm{OH}$ substitutions, is the main spectral feature of the $500^{\circ} \mathrm{C}$ biochar in the fingerprint region. Spectral subtraction of the Hoytville soil and biochar mixtures shows that several of the spectral properties of the biochars are present in the mixtures (Fig. 7b). Soils that received the $300^{\circ} \mathrm{C}$ biochar increased in absorbance at the 2970 to $2830 \mathrm{~cm}^{-1}$ aliphatic band, the 1740 to $1700 \mathrm{~cm}^{-1}$ region, and at $1600 \mathrm{~cm}^{-1}$. Addition of the $500^{\circ} \mathrm{C}$

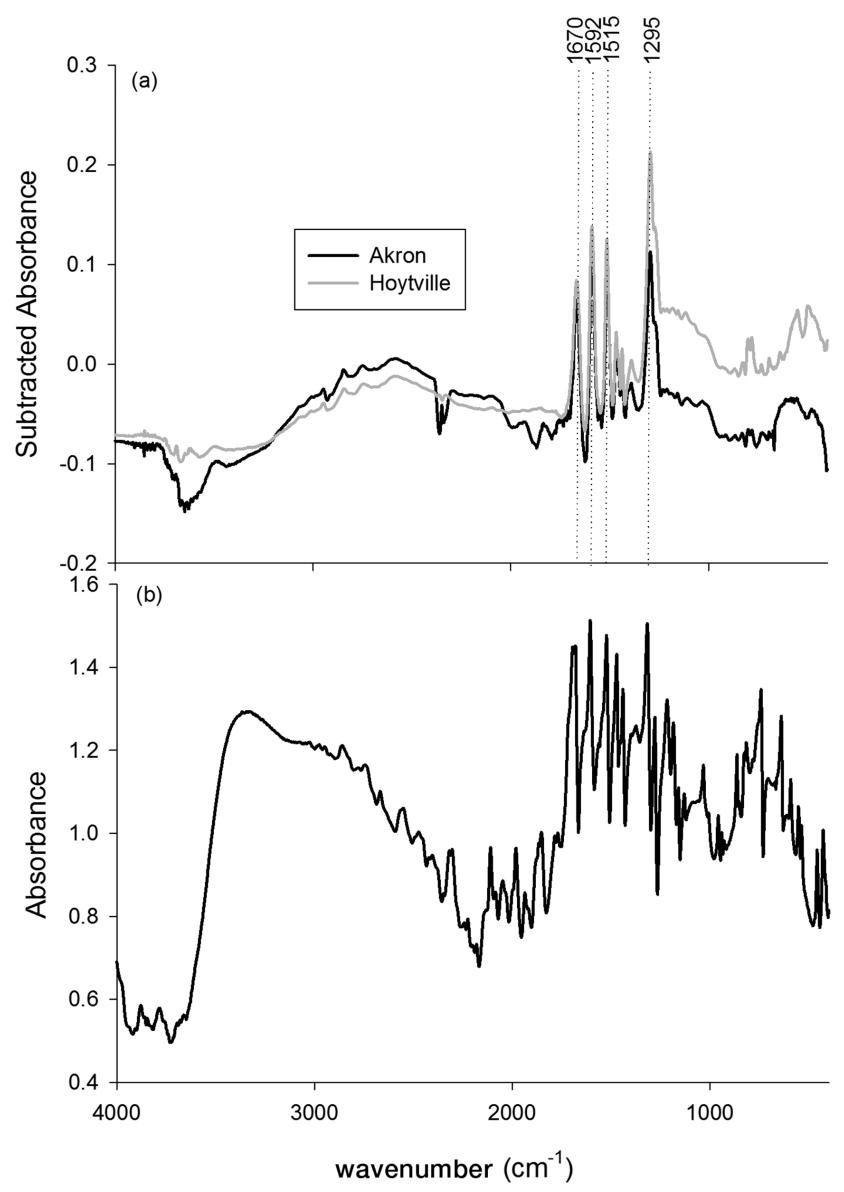

Fig. 6. (a) Spectral subtractions of the vanillin-soil mixes and (b) midinfrared spectra of vanillin.

biochar resulted in higher absorbance at $1600 \mathrm{~cm}^{-1}$ (Fig. 7b), which is the main spectral feature of the $500^{\circ} \mathrm{C}$ biochar.

\section{Mid-Infrared Response to Incremental Additions of Cellulose}

Cellulose was added in three different amounts to increase the soil C by 25,50 , and $100 \%$ for each of the two soils. The following spectral regions responded incrementally to cellulose addition: 3100 to 3500,2930 to 2870 , and 1377 to $1310 \mathrm{~cm}^{-1}$ (Fig. 8). Absorbance around $1100 \mathrm{~cm}^{-1}$, commonly ascribed to carbonyls in polysaccharides (Table 2), was also affected by the incremental addition. The subtractions show that additions of cellulose were associated with higher absorbance in the 1050 to $1200 \mathrm{~cm}^{-1}$ silicate inversion region, suggesting that the cellulose may be coating or blocking the quartz, causing a decrease in the reflection of the infrared beam. In addition, Fig. 8 shows that the addition of cellulose was associated with a possible matrix effect of mineral and soil features in the clay $3630 \mathrm{~cm}^{-1}$ band, the silicate 2000 to $1750 \mathrm{~cm}^{-1}$ region, and a broad region around $1620 \mathrm{~cm}^{-1}$. Absorbance at $1620 \mathrm{~cm}^{-1}$ is due to ring C-C and amide I bands or clay-bound water, which as expected are not present in the pure cellulose spectrum (Table 2; Fig. 3). In the Hoytville soil, the addition of cellulose in the $100 \%$ treatment, which was designed to increase soil C from 2.5 to $5.0 \%$, was associated with an increase 


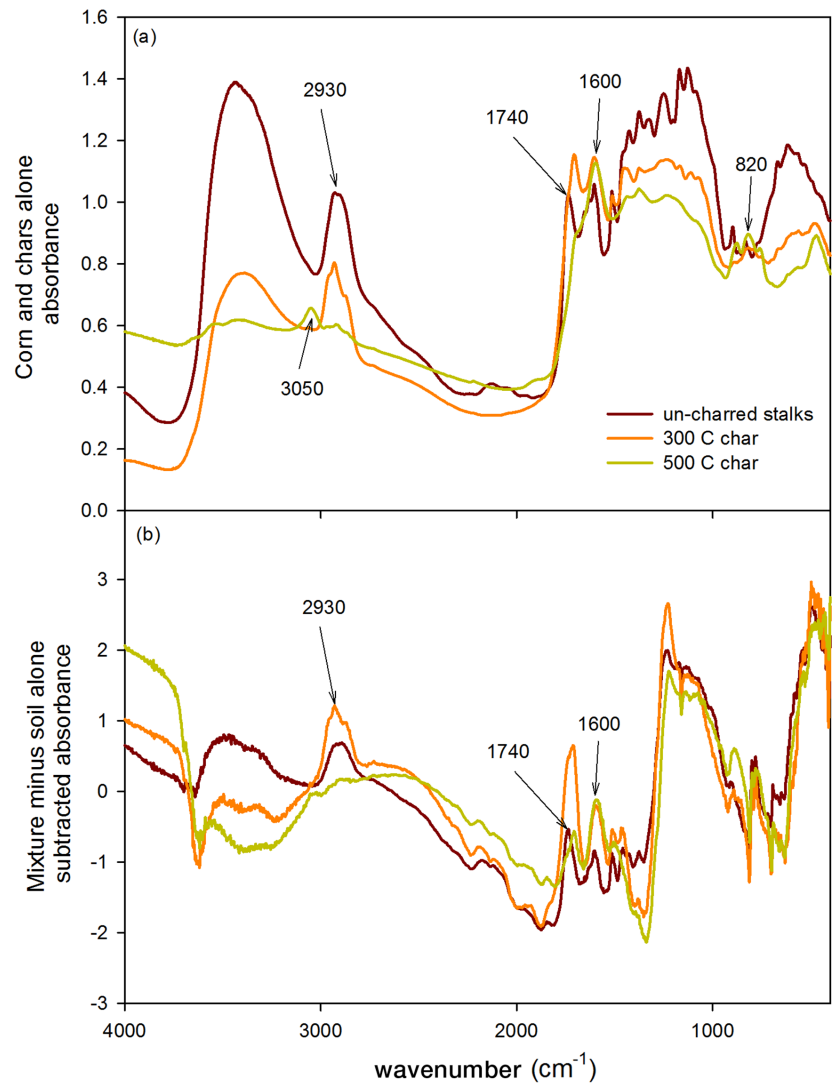

Fig. 7. (a) Mid-infrared spectra of corn stalk feedstock and the chars produced from it at 300 and $500^{\circ} \mathrm{C}$ and (b) spectral subtractions of the soil mixtures minus the Hoytville soil alone.

in absorbance at $3400 \mathrm{~cm}^{-1}$ of $14 \%$, showing that a proportional response in absorbance to soil amendments did not occur.

The absorbances at 1370,2930 , and $3400 \mathrm{~cm}^{-1}$ were chosen for band ratio analyses because they are shown by Fig. 8 to be the most responsive to cellulose addition. Band ratio responses were higher in the Hoytville soils than in the Akron soils (Table 3 ). The ratio of $2930 / 1870 \mathrm{~cm}^{-1}$ was the most sensitive in both soils, reaching a $32 \%$ increase for the $100 \%$ cellulose addition in the Hoytville soil. The absorbance of the individual bands at 1370,2930 , and $3400 \mathrm{~cm}^{-1}$ were less sensitive than the band ratios, with the highest response at $2930 \mathrm{~cm}^{-1}$ in the Hoytville soil reaching $11 \%$ at the highest cellulose rate.

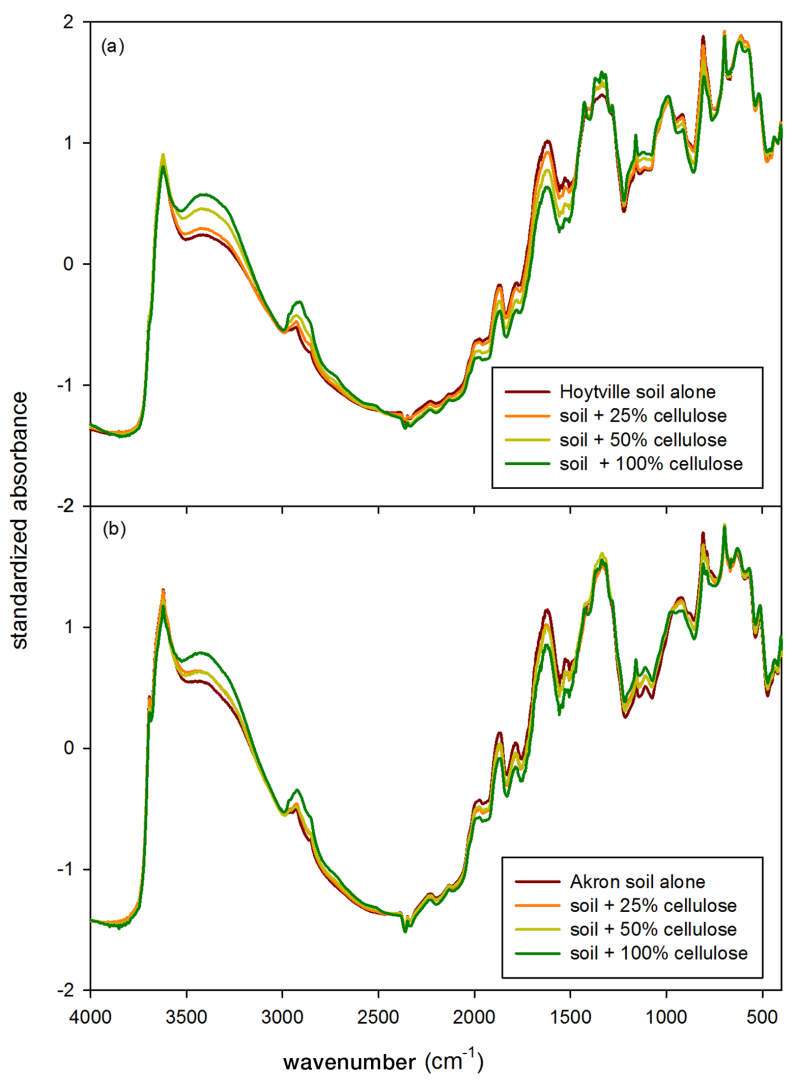

Fig. 8. (a) Hoytville and (b) Akron soils alone and with incremental additions of cellulose; $\mathbf{1 0 0} \%$ represents the quantity of $\mathrm{C}$ standard needed to increase the soil C by $100 \%$.

\section{DISCUSSION}

The spectral differences between the Akron and Hoytville soils are consistent with the higher organic matter content of the Hoytville soil. The lower SOM in the Akron soils could have resulted in proportionately more absorbance at the quartz 2000 to $1790 \mathrm{~cm}^{-1}$ band. Spectral interpretation of clay absorbance, however, was not straightforward. The higher clay content of the Hoytville soil did not cause higher absorbance than the Akron soil at the $3620 \mathrm{~cm}^{-1}$ clay hydroxyl stretching band. This band forms a sharp peak in clay spectra and is mostly absent in organic materials and sands (Nguyen et al., 1991). A SOM coating effect may be the reason, or alternatively, the more weathered type of clays in the Hoytville soils resulted in less absorbance at $3620 \mathrm{~cm}^{-1}$. This is supported by the fact that the Hoytville soil is slower to mineralize $\mathrm{C}$ on long-term incubation

Table 3. Band ratio and individual band responses to cellulose addition. Cellulose was added to Akron and Hoytville soils to increase the soil $\mathrm{C}$ by 25,50 , and $100 \%$.

\begin{tabular}{|c|c|c|c|c|c|c|c|c|}
\hline \multirow{3}{*}{$\begin{array}{l}\text { Band or } \\
\text { band ratio }\end{array}$} & \multirow{2}{*}{\multicolumn{2}{|c|}{ Soils }} & \multicolumn{6}{|c|}{ Soils and cellulose } \\
\hline & & & \multicolumn{2}{|c|}{$25 \% \mathrm{C}$ increase } & \multicolumn{2}{|c|}{$50 \%$ C increase } & \multicolumn{2}{|c|}{$100 \% \mathrm{C}$ increase } \\
\hline & Akron & Hoytville & Akron & Hoytville & Akron & Hoytville & Akron & Hoytville \\
\hline & & & & . & & & & \\
\hline $1370 / 1869$ & $1.60(0.02) \dagger$ & $1.85(0.01)$ & $1.67(0.01)$ & $1.97(0.03)$ & $1.74(0.01)$ & $2.10(0.01)$ & $1.81(0.03)$ & $2.25(0.01)$ \\
\hline $2930 / 1870$ & $0.70(0.01)$ & $0.79(0.01)$ & $0.75(0.03)$ & $0.83(0.02)$ & $0.75(0.03)$ & $0.91(0.02)$ & $0.86(0.05)$ & $1.04(0.03)$ \\
\hline $3400 / 1870$ & $1.19(0.01)$ & $1.23(0.03)$ & $1.26(0.06)$ & $1.28(0.05)$ & $1.30(0.05)$ & $1.44(0.03)$ & $1.41(0.06)$ & $1.61(0.05)$ \\
\hline 1370 & $1.23(0.01)$ & $1.19(0.02)$ & $1.23(0.01)$ & $1.19(0.02)$ & $1.19(0.01)$ & $1.19(0.00)$ & $1.25(0.01)$ & $1.21(0.00)$ \\
\hline 2930 & $0.54(0.02)$ & $0.51(0.01)$ & $0.55(0.02)$ & $0.50(0.01)$ & $0.52(0.03)$ & $0.52(0.01)$ & $0.59(0.02)$ & $0.56(0.02)$ \\
\hline 3400 & $0.92(0.02)$ & $0.79(0.00)$ & $0.92(0.03)$ & $0.77(0.01)$ & $0.90(0.04)$ & $0.81(0.02)$ & $0.97(0.02)$ & $0.87(0.04)$ \\
\hline
\end{tabular}

† Means with SE in parentheses, $n=3$. 
than the Akron soil (Haile-Mariam et al., 2008; Haddix et al., 2011). An intimate organic-clay interaction could lead to a coating effect, shielding clay minerals from infrared absorbance. Pretreatment with HF may be one way to improve the presentation of clay-bound SOM before spectroscopy analyses (Rumpel et al., 2006). These results suggest that spectral interpretation of neat soil spectra from different geographic areas is valuable for hypothesis generation, but specific conclusions about chemical differences need to be drawn with caution because mineralogical differences may introduce artifacts such as the clay phenomenon observed in this study.

The spectral differences suggest that the Akron and Hoytville soils differ not only in the amounts of total $\mathrm{C}$ but also in the quality of the C. Absorbance at 3600 to $3400 \mathrm{~cm}^{-1}$, and to a lesser extent 2930 to 2870,1329 , and $1620 \mathrm{~cm}^{-1}$, are more intense in the Akron soil. The band at 2930 to $2870 \mathrm{~cm}^{-1}$ could be affected by interference from carbonates; however, the acidic $\mathrm{pH}$ of these soils, as well as the absence of the characteristic carbonate band at $2520 \mathrm{~cm}^{-1}$, suggests that carbonate interference is not an issue in the Akron and Hoytville soils and mixtures. The band at $1620 \mathrm{~cm}^{-1}$ for $\mathrm{C}=\mathrm{O}$, or alternatively due to clay-bound water, forms part of a broad and prominent band that spans from 1690 to $1590 \mathrm{~cm}^{-1}$ on many soils and can be seen on the Akron and Hoytville soils (Fig. 7). Incubation of soils results in a rise in absorbance near $1630 \mathrm{~cm}^{-1}$ but a loss in 2930 to $2870 \mathrm{~cm}^{-1}$ in the light fraction, suggesting the degradation of low mean residence time aliphatics into more intermediately available forms (Calderón et al., 2011b). Assis et al. (2012) used absorbance at $1633 \mathrm{~cm}^{-1}$ as a measure of conjugated groups (aromatics, carboxylic acids, quinones). These spectral patterns are in agreement with previous studies showing that the Akron soil contains easier to decompose SOM than the Hoytville soil.

The results of the PCA indicate that the addition of the different organic materials resulted in predictable changes in the soil spectra. The PCA shows that MidIR is very sensitive to increases in proteinaceous or $\mathrm{N}$-containing functional groups in soil. The different amide-like bands at 1670,1588 , and 1513 , as well as $1415 \mathrm{~cm}^{-1}$ increased with the addition of nitrogenous bases, amino acids, and proteins.

Previous work on ashed soils has shown that absorbance between 1700 and $1550 \mathrm{~cm}^{-1}$ has relatively little influence from mineral absorption (Calderón et al., 2011a), so absorbance in these regions can be amenable to spectral interpretation of changes in soil $\mathrm{C}$ chemistry in soils with low clay absorbance. The region between 1750 and $1600 \mathrm{~cm}^{-1}$ can be interpreted, despite the presence of strong silica bands, because silica can be ash subtracted well (Reeves, 2012a). Absorbances at 1554 and $1442 \mathrm{~cm}^{-1}$ are pronounced in native prairie surface soils compared with adjacent soils that have been degraded by cultivation and cropping (Calderón et al., 2011a). This suggests that these spectral changes may be due in part to increases in $\mathrm{N}$ functional groups, associated with changes in the soil $\mathrm{C} / \mathrm{N}$ ratio following cultivation. Absorbance at $1510 \mathrm{~cm}^{-1}$ is highly correlated with soil organic $\mathrm{C}$ according to Haberhauer and Gerzabek (1999), and is also characteristic of the light fraction of SOM (Calderón et al., 2011b); however, absorbance at $1510 \mathrm{~cm}^{-1}$ can also be due to aromatic $\mathrm{C}=\mathrm{C}$ in more recalcitrant fractions of SOM (Baes and Bloom, 1989). Absorbance at $1588 \mathrm{~cm}^{-1}$ is possibly amide II, while absorbance at 1670 $\mathrm{cm}^{-1}$ is amide $\mathrm{I}$. The casein spectrum has prominent peaks from 1700 to 1650 and 1580 to $1500 \mathrm{~cm}^{-1}$. These bands are important in the development of accurate calibrations for soil $\mathrm{C}$ content (Janik et al., 2007). Humic acids, which contain N, also absorb in the 1660 to $1530 \mathrm{~cm}^{-1}$ region (Calderón et al., 2011a).

The spectral subtraction approach supports the hypothesis that MidIR can be a sensitive technique to measure increases in polysaccharides, proteins, and aromatics in soil. The MidIR data show that, as expected, cellulose increased absorbance at 3400 , 2970 to 2800,2200 to 2000 , and 1030 to $1160 \mathrm{~cm}^{-1}$. Bands near 3400 and $2870 \mathrm{~cm}^{-1}$ represent relatively labile $\mathrm{C}$ and decline during decomposition of organic soil amendments (Calderón et al., 2006). Absorbance around $1100 \mathrm{~cm}^{-1}$ has been related to soil aggregation, possibly because of the presence of polysaccharide binding agents in soil (Sarkhot et al., 2007), however, this band is within the inversion caused by specular reflection of silica in neat soils. We hypothesize that carbonyl-rich substances will reduce the inversion effect by direct absorbance in this region, making it a sensitive feature for polysaccharides and other organics.

The methionine and casein subtractions show that bands at 1670 to 1615,1530 to 1490,1450 to 1400,1360 to 1330 , and 1230 to $1170 \mathrm{~cm}^{-1}$ are responsive to protein and amino acid increases due to bands commonly referred to as amide I, amide II, amide III, and C-N stretch. It is important to note, however, that the spectra of amino acids will not have amide bonds unless they react to form proteins, so methionine will not have true amide bands but will still have the $\mathrm{C}=\mathrm{O}$ stretching and $\mathrm{N}-\mathrm{H}$ bending absorptions characteristic of amides. Vanillin increased soil absorbance at $1670 \mathrm{~cm}^{-1}$, showing that this can be from $\mathrm{C}=\mathrm{O}$ absorbance and not necessarily related to $\mathrm{N}$. Vanillin enhanced the aromatic $\mathrm{C}=\mathrm{C}$ bands at 1592,1515 , and $1295 \mathrm{~cm}^{-1}$ (Fig. 6). Decomposition of manure in soils increases the aromatic $\mathrm{C}=\mathrm{C}$ band near $1510 \mathrm{~cm}^{-1}$, showing that this could be an indication of humification and more processed forms of C (Calderón et al., 2006). Demyan et al. (2012) hypothesized that 1660 to $1580 \mathrm{~cm}^{-1}$ is intermediately stable $\mathrm{C}$ in soil spectra, which agrees with some aromatic influence.

The region near $1230 \mathrm{~cm}^{-1}$ is interesting and complex. Soils with high SOM tend to have high absorbance at $1230 \mathrm{~cm}^{-1}$ (Calderón et al., 2011b), as does the clay-sized soil fraction, which has a high mean residence time and contains most of the SOM (Haile-Mariam et al., 2008). The $1230 \mathrm{~cm}^{-1}$ band can be associated with aromatics, as we show with the vanillin amendment (Fig. 6); however, nonaromatic molecules like methionine also absorb in this region, and clays absorb at $1260 \mathrm{~cm}^{-1}$ (Calderón et al., 2011a), so spectral interpretation for this region needs to be done with caution.

The subtraction approach gave less clear results with standards such as egg protein, glucosamine, urease, glycine, and xylose (not shown). We hypothesize that this was in part because these standards contain fewer prominent and defined peaks or low overall absorption in their pure spectra. Indole is thermolabile and melted slightly on scanning, so the spectrum of pure indole was of poor quality. 
The palmitic acid subtraction illustrates how the aliphatic $\mathrm{CH}$ bands between 2970 and $2860 \mathrm{~cm}^{-1}$ respond to lipid addition. Ergosterol caused a smaller response than palmitic acid in this region. Our data show that increases in absorbance between 2970 and $2860 \mathrm{~cm}^{-1}$ indicate an increase in the abundance of $\mathrm{CH}$ bonds in soils with no significant carbonate interference.

It is possible that the egg protein may have non-protein material and be made up of a protein mixture of different conformations, leading to a wide variety of shielding effects and variations in amide absorbances. Different proteins could conceivably vary in their absorbance properties according to the protein size and the degree of denaturation brought about by different temperatures or $\mathrm{pH}$ levels during the purification process. Also, different degrees of cleavage during acid extraction could affect the tertiary and quaternary conformations, causing spectral differences due to variations in intra- and interpeptide shielding. These processes could be associated with unproportional responses of peptide-associated MidIR bands. The MidIR responded semiquantitatively to the additions of cellulose. The bands with the highest absorbance on the pure cellulose spectrum (Fig. 3) were the most responsive to cellulose addition, namely 3100 to 3500,2930 to 2870,1377 to 1310 , and 1220 to $1070 \mathrm{~cm}^{-1}$. The carbonyl band could be particularly important for soil ecology studies. Baldock et al. (1997) found that decomposition of SOM results in an initial reduction of $\mathrm{O}$-containing functional groups such as carbonyls from carbohydrates because of preferential utilization by microbes, which results in an increase of aromatics. It is important to note that xylose, a five-C sugar, did not show the marked increase at $3400 \mathrm{~cm}^{-1}$ on subtraction that was observed in cellulose (not shown), despite pure xylose having a marked absorbance around $3400 \mathrm{~cm}^{-1}$.

Diffuse-reflectance Fourier-transform mid-infrared spectroscopy has been used to show that increasing the temperature during pyrolysis of plant materials results in an initial increase in aromatic bands and later an increase in the carbonaceous nature of the material (Reeves, 2012b). Charring of the corn stalks resulted in a progressive loss of aliphatic functional groups, with a corresponding increase in aromatic bands. This progression in the chemistry of charred organic materials, first losing aliphatics, then gaining aromatic character, is consistent with ${ }^{13} \mathrm{C}$ NMR data from different temperature biochars (Novak et al., 2009). Spectral subtraction shows that, like the pure standards, the more prominent spectral features of the biochar predictably affect the spectra of the soil biochar mixtures. Aliphatic and carbonyl features still present in the $300^{\circ} \mathrm{C}$ biochar subtract well, and so does the aromatic band at 1600 in the $500^{\circ} \mathrm{C}$ biochar. In this study, we chose moderate charring temperatures because higher temperatures will result in a graphite-like material (Reeves, 2012b). Without absorbance bands, a highly carbonized biochar is less amenable for the identification of biochar bands via spectral subtraction in soil mixtures. Biochars of higher temperatures, such as those prepared at $700^{\circ} \mathrm{C}$, lose most of their functional groups and start to attain spectral differences that may be due to particle size or carbonization artifacts (Reeves, 2012b).

Our results suggest that the effects of adding a substance to a complex mixture such as soil will be partly due to the direct absorbance of the added chemical but also due to matrix effects of the soil organics and minerals in regions where the amendment is not particularly absorptive. This may be responsible for deviations in the Beer-Lambert law. The matrix effect was illustrated by the reduction of the clay $3630 \mathrm{~cm}^{-1}$ and the silicate 2000 to 1750 $\mathrm{cm}^{-1}$ bands, where pure cellulose does not absorb. We hypothesize that a coating of soil minerals by the added cellulose would reduce the exposure of the minerals to the infrared, thus reducing the typical mineral bands. Cellulose can also mask organic bands. Figure 3 shows that pure cellulose does not absorb significantly in the 1720 to $1500 \mathrm{~cm}^{-1}$ region and reduces absorbance in this spectral range on addition to soil (Fig. 7). This region includes the amide bands that have been correlated with microbial biomass (Calderón et al., 2011a) or a carbonyl $\mathrm{C}=\mathrm{O}$ band/aromatic $\mathrm{C}=\mathrm{C}$ common in humified organic matter (Shirshova et al., 2006).

Band ratios were shown to be more sensitive to cellulose addition than individual selected bands. Band ratios are particularly sensitive to changes in SOM because ratios reduce baseline effects, normalize the data, and emphasize particular features of the spectrum that are assumed to be important. For example, we show that the ratio of $2930 / 1870 \mathrm{~cm}^{-1}$ could be used to detect specific changes in SOM. The $2930 \mathrm{~cm}^{-1}$ band is an aliphatic $\mathrm{CH}$ band that is relatively free of mineral interference in carbonate-free soils (Leifeld, 2006), while $1870 \mathrm{~cm}^{-1}$ is a silicate band that should have little or no influence from organics. Thus, $2930 / 1870 \mathrm{~cm}^{-1}$ effectively emphasizes fluctuations in the organics. This is accentuated by the fact that soils lower in organic matter also have higher absorbance in the mineral bands (Pedersen et al., 2011).

Other recent studies have also shown the usefulness of the band ratio approach. Artz et al. (2006) characterized the decomposability of $\mathrm{SOM}$ by calculating the ratio of carboxylate to polysaccharide bands. Others have used band ratios as indicators of SOM resistance to decomposition (Demyan et al., 2012; Assis et al. (2012). Ellerbrock et al. (2005) used band ratios to study the hydrophobic or hydrophilic nature of SOM. Matějková and Šimon (2012) used the different ratio of $1633 / 2929 \mathrm{~cm}^{-1}$ to indicate the proportion of conjugated to aliphatic functional groups in SOM.

\section{CONCLUSIONS}

1. Our work shows that when small amounts of standard organics are added to soil, it is possible to detect changes in the soil spectrum that correspond to characteristic features of many of the added chemicals.

2. Comparisons of soils from different parent materials or clay mineralogy must take into account that soil minerals strongly affect soil spectra.

3. This research evaluated the addition of pure standards to dry soil. Adding a material to soil could be different from resident SOM, both in terms of chemistry and in terms of sample presentation. Some of the older SOM is closely associated with clay minerals, diminishing their presentation of the organics to the spectrometer. Amendments could coat the soil particles via electrostatic attraction and cause matrix effects because of the low penetration depth of the MidIR.

4. These studies confirm the useful nature of MidIR for 
overall soil characterization and the measurement of general constituents; MidIR was responsive to many of the individual standards added, but glucosamine, egg protein, and urease did not give as clear results as some of the simpler standards. Band assignments were more complicated as chemical complexity increased; MidIR did not respond in a linear manner to substrate addition, indicating that it is not as useful for measuring the amount of individual chemical components as it is for general soil quality determination.

\section{ACKNOWLEDGMENTS}

We thank Sean Maloney for his assistance with sample preparation. Thanks to Merle Vigil, Andrew Margenot, and Sanjai Parikh for critical review of the manuscript.

\section{REFERENCES}

Artz, R.R.E., S.J. Chapman, and C.D. Campbell. 2006. Substrate utilisation profiles of microbial communities in peat are depth dependent and correlate with whole soil FTIR profiles. Soil Biol. Biochem. 38:2958-2962. doi:10.1016/j.soilbio.2006.04.017

Assis, C.P., I. Jucksch, E.S. Mendonça, J.C.L. Neves, L.H.M. Silva, and B. Wendling. 2012. Distribution and quality of the organic matter in light and heavy fractions of a Red Latosol under different uses and management practices. Commun. Soil Sci. Plant Anal. 43:835-846. doi:10.1080/00103624.2012.648469

Baes, A.U., and P.R. Bloom. 1989. Diffuse reflectance and transmission Fourier transform infrared (DRIFT) spectroscopy of humic and fulvic acids. Soil Sci. Soc. Am. J. 53:695-700. doi:10.2136/sssaj1989.03615995005300030008x

Baldock, J.A., J.M. Oades, P.N. Nelson, T.M. Skene, A. Golchin, and P. Clarke. 1997. Assessing the extent of decomposition of natural organic materials using solid-state ${ }^{13}$ C NMR spectroscopy. Aust. J. Soil Res. 35:1061-1083. doi:10.1071/S97004

Bellon-Maurel, V., and A. McBratney. 2011. Near-infrared (NIR) and mid-infrared (MIR) spectroscopic techniques for assessing the amount of carbon stock in soils: Critical review and research perspectives. Soil Biol. Biochem. 43:1398-1410. doi:10.1016/j.soilbio.2011.02.019

Calderón, F.J., G.W. McCarty, and J.B. Reeves III. 2006. Pyrolisis-MS and FT-IR analysis of fresh and decomposed dairy manure. J. Anal. Appl. Pyrolysis 76:14-23. doi:10.1016/j.jaap.2005.06.009

Calderón, F.J., M.M. Mikha, M.F. Vigil, D.C. Nielsen, J.G. Benjamin, and J.B. Reeves III. 2011a. Diffuse-reflectance mid-infrared spectral properties of soils under alternative crop rotations in a semi-arid climate. Commun. Soil Sci. Plant Anal. 42:2143-2159. doi:10.1080/00103624.2011.596243

Calderón, F.., J.B. Reeves III, H.P. Collins, and E.A. Paul. 2011b. Chemical differences in soil organic matter fractions determined by diffuse-reflectance mid-infrared spectroscopy. Soil Sci. Soc. Am. J. 75:568-579. doi:10.2136/sssaj2009.0375

Calderón, F.J., D.J. Schultz, and E.A. Paul. 2012. Carbon allocation, belowground transfers, and lipid turnover in a plant-microbial association. Soil Sci. Soc. Am. J. 76:1614-1623. doi:10.2136/sssaj2011.0440

Cox, R.J., H.L. Peterson, J. Young, C. Cusik, and E.O. Espinoza. 2000. The forensic analysis of soil organic by FTIR. Forensic Sci. Int. 108:107-116. doi:10.1016/ S0379-0738(99)00203-0

Davinic, M., L.M. Fultz, V. Acosta-Martinez, FJ. Calderón, S.R. Cox, S.E. Dowd, et al. 2012. Pyrosequencing and mid-infrared spectroscopy reveal distinct aggregate stratification of soil bacterial communities and organic matter composition. Soil Biol. Biochem. 46:63-72. doi:10.1016/j.soilbio.2011.11.012

Demyan, M.S., F. Rasche, E. Schulz, M. Breulmann, T. Müller, and G. Cadisch. 2012 Use of specific peaks obtained by diffuse reflectance Fourier transform mid-infrared spectroscopy to study the composition of organic matter in a Haplic Chernozem. Eur. J. Soil Sci. 63:189-199. doi:10.1111/j.1365-2389.2011.01420.x

Ellerbrock, R.H., H.H. Gerke, J. Bachmann, and M.-O. Goebel. 2005. Composition of organic matter fractions for explaining wettability of three forest soils. Soil Sci. Soc. Am. J. 69:57-66. doi:10.2136/sssaj2005.0057

Follett, R.F., E.A. Paul, and E.G. Pruessner. 2007. Soil carbon dynamics during a longterm incubation study involving ${ }^{13} \mathrm{C}$ and ${ }^{14} \mathrm{C}$ measurements. Soil Sci. 172:189208. doi:10.1097/ss.0b013e31803403de

Haberhauer, G., and M.H. Gerzabek. 1999. Drift and transmission FT-IR spectroscopy of forest soils: An approach to determine decomposition processes of forest litter. Vib. Spectrosc. 19:413-417. doi:10.1016/S0924-2031(98)00046-0

Haddix, M.L., A.F. Plante, R.T. Conant, J. Six, J.M. Steinweg, K. Magrini-Bair, et al. 2011. The role of soil characteristics on temperature sensitivity of soil organic matter. Soil Sci. Soc. Am. J. 75:56-68. doi:10.2136/sssaj2010.0118

Haile-Mariam, S., H.P. Collins, S. Wright, and E.A. Paul. 2008. Fractionation and long-term laboratory incubation to measure soil organic matter dynamics. Soil Sci. Soc. Am. J. 72:370-378. doi:10.2136/sssaj2007.0126

Hemminga, M.A., and P. Buurman. 1997. Editorial: NMR in soil science. Geoderma 80:221-224. doi:10.1016/S0016-7061(97)00053-0

Janik, L.J., J. Skjemstad, K. Shepherd, and L. Spouncer. 2007. The prediction of soil carbon fractions using mid-infrared-partial least square analysis. Aust. J. Soil Res. 45:73-81. doi:10.1071/SR06083

Leifeld, J. 2006. Application of diffuse reflectance FT-IR spectroscopy and partial least squares regression to predict NMR properties of soil organic matter. Eur. J. Soil Sci. 57:846-857. doi:10.1111/j.1365-2389.2005.00776.x

Magrini, K.A., R.F. Follett, J. Kimble, M.F. Davis, and E. Pruessner. 2007. Using pyrolysis molecular beam mass spectrometry to characterize soil organic carbon in native prairie soils. Soil Sci. 172:659-672. doi:10.1097/ss.0b013e3180d0a3a5

Matějková, Š., and T. Šimon. 2012. Application of FTIR spectroscopy for evaluation of hydrophobic/hydrophilic organic components in arable soil. Plant Soil Environ. 58:192-195.

McCarty, G.W., J.B. Reeves III, V.B. Reeves, R.F. Follett, and M. Kimble. 2002. Midinfrared and near infrared diffuse reflectance spectroscopy for soil carbon measurement. Soil Sci. Soc. Am. J. 66:640-646. doi:10.2136/sssaj2002.0640

Movasaghi, Z., S. Rehman, and I. ur Rehman. 2008. Fourier transform infrared (FTIR) spectroscopy of biological tissues. Appl. Spectrosc. Rev.. 43:134-179. doi:10.1080/05704920701829043

Nguyen, T., L.J. Janik, and M. Raupach. 1991. Diffuse reflectance infrared Fourier transform (DRIFT) spectroscopy in soil studies. Aust. J. Soil Res. 29:49-67. doi:10.1071/SR9910049

Novak, J.M., I. Lima, B. Xing, J.W. Gaskin, C. Steiner, K.C. Das, et al. 2009. Characterization of designer biochar produced at different temperatures and their effects on a loamy sand. Ann. Environ. Sci. 3:195-206.

Paul, E.A., R.F. Follett, S.W. Leavitt, A. Halvorson, G.A. Peterson, and D.J. Lyon. 1997. Radiocarbon dating for determination of soil organic matter pool sizes and dynamics. Soil Sci. Soc. Am. J. 61:1058-1067. doi:10.2136/ sssaj1997.03615995006100040011x

Paul, E.A., S.J. Morris, R.T. Connant, and A.F. Plante. 2006. Does the hydrolysisincubation method measure meaningful soil carbon pools? Soil Sci. Soc. Am. J. 70:1023-1035. doi:10.2136/sssaj2005.0103

Pedersen, J.A., M.A. Simpson, J.G. Bockheim, and K. Kumar. 2011. Characterization of soil organic carbon in drained thaw-lake basins of arctic Alaska using NMR and FTIR photoacoustic spectroscopy. Org. Geochem. 42:947-954. doi:10.1016/j. orggeochem.2011.04.003

Reeves, J.B., III. 2012a. Mid-infrared spectral interpretation of soils: Is it practical or accurate? Geoderma 189-190:508-513 doi:10.1016/j.geoderma.2012.06.008

Reeves, J.B., III. 2012b. Mid-infrared spectroscopy of biochars and spectral similarities to coal and kerogens: What are the implications? Appl. Spectrosc. 66:689695. doi:10.1366/11-06478

Rumpel, C., N. Rabia, S. Derenne, K. Quenea, K. Eusterhues, I. Kögel-Knabner, and A. Mariotti. 2006. Alteration of soil organic matter following treatment with hydrofluoric acid (HF). Org. Geochem. 37:1437-1451. doi:10.1016/j.orggeochem.2006.07.001

Sarkhot, D.V., N.B. Comerford, E.J. Jokela, J.B. Reeves III, and W.G. Harris. 2007. Aggregation and aggregate carbon in a forested southeastern Coastal Plain Spodosol. S. Soil Sci. Soc. Am. J. 71:1779-1787. doi:10.2136/sssaj2006.0340

Shirshova, L.T., E.A. Ghabbour, and G. Davies. 2006. Spectroscopic characterization of humic acid fractions isolated from soil using different extraction procedures. Geoderma 133:204-216. doi:10.1016/j.geoderma.2005.07.007

Steelink, C. 2002. Investigating humic acids in soils. Anal. Chem. 74:326A-333A. doi: $10.1021 / \mathrm{ac} 022040 \mathrm{~m}$

Stout, J.D., K.M. Goh, and T.A. Rafter. 1981. Chemistry and turnover of naturally occurring resistant organic compounds in soil. In: E.A. Paul and N. Ladd, editors, Soil biochemistry. Vol. 5. Marcel Dekker, New York. p. 1-73.

Thevenot, M., M.F. Dignac, and C. Rumpel. 2010. Fate of lignins in soils: A review. Soil Biol. Biochem. 42:1200-1211. doi:10.1016/j.soilbio.2010.03.017

Viscarra Rossel, R.A., D.J.J. Walvoort, A.B. McBratney, L.J. Janik, and J.O. Skjemstad. 2006. Visible, near-infrared, mid-infrared or combined diffuse reflectance spectroscopy for simultaneous assessment of various soil properties. Geoderma 131:59-75. doi:10.1016/j.geoderma.2005.03.007 